\title{
Customer Perceptions of Product Luwak Coffee based on Marketing Mix Elements Perspective (Customer Survey In Bandung)
}

\author{
Bunga Indah Bayunitri \\ Faculty of Economy - Widyatama University \\ Indonesia \\ bunga.indah@widyatama.ac.id
}

\begin{abstract}
Coffee is the commodities which plays an important role in the Indonesian economy. In recent years, Indonesia began ogled by the world related Luwak coffee that are produced and judged to have great business potential in Indonesia. According to the Association of Indonesian Coffee Exports (AICE) said that Luwak coffee prices on the world market through between Rp $5,000,000$ - Rp 8,000,000 per kilogram.

Related with the business growth, it became the demands of the industry in creating customer satisfaction especially after the purchase of which eventually formed a customer loyalty to the product through vigorous marketing mix consists of product, price, place and distribution (Simamora, 2001).

This type of research used in this research is qualitative research to understand the phenomenon of what is experienced by research subjects holistically, and using of descriptive design to solving the problems that exist now based on the data. As well as methods of data collection in this research is using survey method.

The results of this study regarding the customer's perception of the elements of the marketing mix for a Luwak coffee, is not good enough. Although the views from the elements already excellent quality so that can penetrate into the international market, but for other elements such as price, place and promotion is still deficient.
\end{abstract}

Keywords-Customer's perception, Customer satisfaction, Elements of the marketing mix, Luwak coffee, Marketing mix.

\section{Introduction}

Coffee is an alternative drink that is a great demand of Indonesian. Indonesia itself is a coffee producer that is quite famous in the world that is ranked fourth after Brazil, Vietnam, and Colombia.

Based on information from Ditjenbun (2013) states that coffee is a plantation commodity on the economic field in the Indonesia, which is the main source of income of Indonesian less than 1.84 million families mostly in rural areas. Coffee is also an important export commodity for Indonesia that provide a large foreign exchange in 2010, that the area of coffee plantation reaches $1,210,365$ ha with production 686.92 tons and export volume 433,595 tons or equivalent to US \$ 814.311.000.

In recent years, coffee products from Indonesia has begun to be glimpsed by the world and considered to have big business potential in Indonesia particularly is Luwak coffee. Luwak coffee is produced from the fermentation process of coffee beans through the stomach until the feces that consumed by the mongoose. With the help of enzymes in the digestive system of the mongoose was able to reduce the acid levels in coffee beans, so the result is the coffee beans have a unique taste and aroma image.

According to the Association of Indonesian Coffee Exports (AEKI), the price of kopi luwak in world can penetrate between Rp 5,000,000 - Rp 8,000,000 per kilogram. Not only the high selling point but the demand from the world market also raise up, so the effect to the rapid growth of trading businesses in Indonesia.

Concerning with the business growth, businesspeople must be able to design marketing strategies in order to win the competition. It becomes the demands of every company in creating customer satisfaction and loyalty through a vigorous marketing mix consisting of product, price, place and distribution (Simamora, 2001).

However, the behind of the success of Luwak coffee business, there are the reaction of some people who condemned the existence of animal welfare. The Ministry of Trade (MoHA) has defended the black-and-white campaign against Luwak Coffee products that criticized for neglecting civet welfare problem or known as civet (animal walfare). As a result, the fate of Kopi Luwak this country is difficult to enter the EU market (Fiki Ariyanti, 2015).

Based on the exposure before, the authors analyze customer perceptions of luwak coffee products based on the perspective of marketing mix elements. On the basis of the author entitled: "Customer Perceptions of Luwak Coffee Products Based on Perspective Elements of Marketing Mix (Customer Survey at Bandung)".

Based on the above background, then it can be taken a problem formulation as follows: "How is the customer perception of the product Luwak coffee based on the perspective elements marketing mix?" 


\section{THEORETICAL FRAMEWORK}

\section{A. Definition of Marketing Management}

According to the American Marketing Association (AMA) quoted in Philip Kotler and Kevin Lane Keller (2012) that marketing management is a set of processes to create, communicate, and deliver value to customers and manage customer relationships to benefit organizations and stakeholders.

\section{B. Definition of Marketing Mix}

The basic strategy of marketing which must be done by a marketing manager is to use a marketing mix strategy. That strategy has an important role in the company to win the market by influencing consumers to purchase the product.

Definition of marketing mix according to Kotler and Armstrong (2012) are:

"Marketing mix is good marketing tool is a set of products, pricing, promotion, distribution, and combined to produce the desired response of the target market."

While the definition of marketing mix from other experts that according to Buchari (2008) are:

"Marketing mix is a strategy to mix marketing activities, to find the maximum combination so that the most satisfying results."

\section{Element of Marketing Mix}

According to the American Marketing Association (AMA) quoted in Philip Kotler and Kevin Lane Keller (2012) that marketing management is a set of processes to create, communicate, and deliver value to customers and manage customer relationships to benefit organizations and stakeholders.

In Tjiptono's opinion (2012) that there are four elements in the marketing mix used by marketers to market their products that include:

1. Product

Products offered to consumers are goods, services, people or persons, places, organizations, and ideas that have tangible and intangible benefits in satisfying the customer. Here are the product attributes that can be used as the basis for making a purchase decision, namely:

\section{a. Brand}

Brand is the name, term, sign, symbol, design, color, motion, which is expected to give the identity and differentiation to the competitor's product.

b. Packaging

Packaging is the process of designing and packaging for products.

c. Service
Service is a characteristic form of image of a product that is intangible.

d. Warranty

Product warranties are used to convince consumers that the company will replace the purchased product if there is a discrepancy.

2. Price

According to Tjiptono (2012) the price is a monetary unit to acquire the right of ownership or use of a good or service. The purpose of pricing there are four types:

a. Profit-Oriented Goals

Each company chooses the highest profitgenerating price known as profit maximization.

b. Volume-Oriented Goals

The price is set to achieve the target sales volume or market share.

c. Image-Oriented Goals

Companies can set a high price to establish or maintain an image.

\section{d. Price Stabilization Goals}

Price stability is needed in markets where consumers are very price sensitive.

3. Place

It is an enterprise activity to channel, teach, and deliver products available to target consumers with distribution channels.

The intermediary is the person or company that connects the flow of goods from the producer to the final consumer. Intermediaries are divided into middleman merchants (intermediaries with merchandise for resale) and middleman agents (intermediaries seeking buyers, negotiating and making transactions).

4. Promotion

Based on Tjiptono (2002) promotion is all activities to communicate products to consumers to provide information about the features, usefulness, and existence of the product. The main purpose is in addition to informing also to persuade customers to consume products. 


\section{III.RESEARCH METHOD}

\section{A. Types of Research}

The type of research used in this research is qualitative research to understand the phenomenon of what is experienced by the subject of research holistically by describing the form of words and language in a specific context that is natural and using various scientific methods (Moleong, 2007: 6).

In this research is also used qualitative method with descriptive design for problem solving that exist based on data, that is research by giving description about condition and symptom of individual or group in detail.

Data collection method in this research is using survey method which is method to get data from certain place, for example by distributing test questionnaire, structured interview, and so on (Sugiyono, 2012).

\section{B. Data Collection Techniques}

Data collection techniques in this research are:

1. Observation

Observations are used to observe in the field the data previously collected for confirmation directly or indirectly.

\section{Interview}

According Sugiyono (2008) interview is a two-party meeting to exchange information and ideas through question and answer in a topic to find its meaning.

\section{Documentation}

Based on Suharsimi Arikunto (2002) method of documentation, that is looking for source data derived from notes, books, newspapers, magazines, and so forth.

\section{The Subject of Research}

In this research, the research subjects were customer with the criteria, including: Bandung Domicile (KTP Bandung), aged 25-39 years (most coffee drinkers based on National Coffee Association data in 2011), have knowledge about coffee, and have experience consuming Luwak coffee.

The sample used in this research is saturated sampling. According to Riduwan (2012: 64) that saturated sampling is a sampling technique when all populations are used as a sample and also known as the census. Saturated sampling is performed when the population is less than 30 people.

Other than that, the sampling of this research using accidental sampling technique is a research technique based on chance, anyone who by chance meet with the researcher can be used as sample which is considered suitable as data source (Sugiyono, 2010: 67).

\section{The Object of Research}

Objects in this study related to the elements of marketing mix strategy are as follows:
TABLE I.

DETAILED OF OBJECT RESEARCH

\begin{tabular}{|c|c|c|c|}
\hline PROBLEMS & DIMENTION & INDICATOR & METHOD \\
\hline \multirow{4}{*}{$\begin{array}{l}\text { How does the } \\
\text { customer } \\
\text { perception of } \\
\text { luwak coffee } \\
\text { product based } \\
\text { on the } \\
\text { perspective } \\
\text { of marketing } \\
\text { mix } \\
\text { elements? }\end{array}$} & Product & $\begin{array}{l}\text { 1. Product quality } \\
\text { (ingredients, } \\
\text { flavor and } \\
\text { aroma) } \\
\text { 2. Durability of } \\
\text { product } \\
\text { 3. Packaging of } \\
\text { product }\end{array}$ & \multirow{4}{*}{$\begin{array}{c}\text { Observation } \\
\text { and } \\
\text { Interview }\end{array}$} \\
\hline & Price & $\begin{array}{l}\text { 4. Affordability } \\
\text { of price } \\
\text { 5. Price according } \\
\text { to product } \\
\text { quality }\end{array}$ & \\
\hline & Place & $\begin{array}{l}\text { 6. Ease of getting } \\
\text { the product } \\
\text { 7. Availability of } \\
\text { supplies in } \\
\text { intermediaries/ } \\
\text { distributors }\end{array}$ & \\
\hline & Promotion & $\begin{array}{l}\text { 8. Online and } \\
\text { offline } \\
\text { promotion } \\
\text { media } \\
\text { 9. Product } \\
\text { sampling } \\
\text { 10. Discount }\end{array}$ & \\
\hline
\end{tabular}

\section{E. Data Analysis Method}

Methods of data analysis in this study by Burhan Bungin (2003: 70) using the steps as follows:

\section{Data Collection}

Data collection is an integral part of data analysis activities. Data collection activities in this study by using observation, interview and documentation study.

\section{Data Reduction}

Are selection process, focusing attention on simplification and transformation of rough data arising from written records from the field. Reduction is done by summarizing, coding, tracking themes, creating clusters, and writing memos with the intention of excluding irrelevant data/ information.

\section{Display}

DataThe presentation of data is the description of a set of arranged information that provides the possibility of conclusion and action taking. The presentation of qualitative data is presented in the form of narrative text (can be matrices, diagrams, tables and charts).

4. Verification and Conclusion 
Withdrawal of conclusions in the form of interpretation activities, namely finding the meaning of data that has been presented. Between data display and conclusion there are data analysis activities. Qualitative data analysis is an ongoing, repetitive and ongoing effort. Data reduction, data presentation and conclusion / verification are success stories in sequence as a series of related analytical activities. Further data that has been analyzed, explained and interpreted in the form of words to describe the facts in the field and to answer research questions that are then taken conclusions only.

\section{IV.RESULT AND DISCUSSION}

Customer perceptions of Luwak products based on the perspective of marketing mix elements consisting of:

\section{Product}

Based on the results of interviews of respondents related to the quality of Luwak coffee products that the quality of Luwak coffee is very good. The bitterness is low but does not diminish the flavor of the coffee. The aroma of Luwak coffee is very unique, not pungent, but still has a distinctive aroma of coffee. The resistance of Luwak coffee is quite good because coffee is basically a commodity that has a high endurance.

However, related to product packaging is still needed improvement, because in addition to the aesthetics of the most important product is to protect the materials in the packaging. Moreover, the product has been exported to countries that are very strict against the entry of foreign products such as the United States and other European countries including the packaging used. The packaging shall use safe ingredients for food or drink and there shall be a label informing the entire ingredient of the product as well as the use of the product.

2. Price

Based on the results of interviews on respondents, that related elements of the price that Luwak coffee is a commodity that has a high price for the domestic market even for the international market. Therefore, many customers who can't reach the selling price of the kopi luwak. Usually the selling price of one cup of coffee sold by cafes 5 stars in a big city that is Rp 150,000. From this high selling price, chances are only a few people who have experience in consuming Luwak coffee. Although now appears instant coffee Luwak mass marketed by the manufacturer, but it feels different with the non-instant coffee Luwak.

According to the customer perception that the high price is in accordance with the quality of the product, because the production of Luwak coffee is not easy, not the same as the coffee production process in general. Luwak coffee production is produced from the fermentation process that has an enzyme in the digestive system of mongoose through the stomach mongoose that consume the coffee is then issued in the form of feces. The enzyme can reduce the acid levels in coffee beans, so the resulting coffee beans have a unique taste and aroma image.

\section{Place}

Based on result of the research, that perception of customer to element of place is seen from indicator of easiness in getting product and availability of coffee supply at distributor.

Customers to enjoy Luwak coffee is now quite easy to find in coffee cafes in big cities of Indonesia. But if you want to buy coffee products in the form of certain packaging is still not easy enough because as previously discussed that more luwak coffee sent to the international market because of the demand from the market with a very promising price. So that the availability of Luwak coffee inventory at the distributor was sometimes not available, because it must enter the production of these coffees to the international market first.

\section{Promotion}

The customer's perception of promotional elements in the marketing mix is the first seen from the indicator of online and offline promotion media. According to customer, the promotion of Luwak coffee, especially in Indonesia, is still very poor, online and offline media. Although it is indeed the Luwak coffee demand from the international market is high but if able to create a good promotional strategy will increase market growth opportunities.

The second and third indicators are in the sample and the discount is still very minimal. This is possible because the availability of Luwak coffee for the domestic market was still minimal so that the sample is still low. And also the high price factor is also causing the sample is still low.

\section{CONCLUSION AND SUGGESTION}

Based on the results of data processing and discussion, the authors can conclude the conclusion about customer perceptions of elements of marketing mix for Luwak coffee products is not good enough. Although viewed from the element of quality is very good until it can penetrate to the international market, but for other elements such as price, place, and promotion is still minimal.

Especially for elements of the place associated with consumer convenience to get the product is still difficult. That can be only founded in five-star coffee cafes in big cities and in some areas of the island of Bali which is the biggest coffee Luwak producer in Indonesia. In addition, the promotion is still minimal either through online media or offline media.

Based on the results of research, the suggestions that can be used as input to be implemented in the business area are:

1. Related promotions should use both online media and offline media. Moreover, because the product is worldwide, it should be more appropriate to use online media by using internt in marketing its products so that the dissemination of product information more quickly, widely, and efficiently seen from the cost. Online media is to use social media to 
attract more customers such as websites, blogs, facebook, twitter, path, and so forth.

2. While the distribution of the place should be recommended to be further enhanced by opening more coffee outlets and held a coffee bazaar for Luwak coffee is increasingly famous not only overseas but increasing the domestic market too. Because the domestic market also has a large number of potential customers are very much in accordance with the number of Indonesian population which reached more than 200 million. It is a potential market share for wider product distribution and higher profitability opportunities.

\section{REFERENCES}

[1] AEKI. 2014. Industri Kopi Indonesia.Retrieved from: http://www.aeki-aice.org/page/industrikopi/id

[2] Arikunto, Suharsimi. 2002. Metodologi Penelitian. Jakarta: penerbit PT. Rineka Cipta.

[3] Ariyanti, Fiki. 2015. Produksi Kopi Luwak RI Dikecam, Ini Reaksi Kemendag. Retrieved from: http://bisnis.liputan6.com/read/2214929/produksi-kopiluwak-ri-dikecam-ini-reaksi-kemendagl

[4] Bilson, Simamora. 2001. Memenangkan Pasar Dengan Pemasaran Efektif dan Profitabel. Jakarta: PT. Gramedia Pustaka Utama

[5] Buchari, Alma. 2008. Manajemen Pemasaran dan Pemasaran Jasa. Bandung: Alfabeta

[6] Bungin, Burhan. 2003. Analisis Data Penelitian Kualitatif . Jakarta: PT Raja Grafindo Persada

[7] Ditjenbun. 2013. Kopi Berkelanjutan. Retrieved from: http://ditjenbun.pertanian.go.id/pascapanen/berita-203kopi-berkelanjutan-.htm

[8] Hermawan, Haris. 2015. Analisis Pengaruh Bauran Pemasaran terhadap Keputusan, Kepuasan, dan Loyalitas Konsumen dalam Pembelian Roti Ceria di Jember. Jurnal Manajemen dan Bisnis Indonesia. Vol. 1, No. 2.

[9] Kotler, Philip dan Gary Armstrong. 2012. Prinsip-prinsip Pemasaran. Edisi 13. Jilid 1. Jakarta: Erlangga.

[10] Kotler, Philip dan Kevin Lane Keller. 2012. Marketing Management. 14th Edition. United States of America: Pearson.

[11] Mevita, Afrida Shela. 2013. Pengaruh Bauran Pemasaran terhadap Kepuasan Konsumen. Jurnal Ilmu dan Riset Manajemen. Vol. 2 No. 9.

[12] Moleong, Lexy J. 2007. Metodologi Penelitian Kualitatif. Bandung: Penerbit PT Remaja Rosdakarya Offset.

[13] National Coffee Association USA. 2011. What is coffee?. Retrieved http://www.ncausa.org/i4a/pages/index.cfm?pageid=67.

[14] Riduwan. 2012. Metode dan eknik Menyusun Proposal Penelitian. Bandung: Alfabeta.
[15] Rubiyo. 2013. Pengaruh Fermentasi Terhadap Citarasa Kopi Luwak Probiotik. IAARD E-Journal. Volume 4, No 2.

[16] Selang, Christian. 2013. Bauran Pemasaran Pengaruhnya terhadap Loyalitas Konsumen pada Fresh Mart Bahu Mall Manado. Jurnal EMBA. Vol. 1, No. 3, Hal. 71-80.

[17] Sugiyono. 2008. Metode Penelitian Kunatitatif Kualitatif dan R\&D. Bandung: Penerbit Alfabeta.

[18] Sugiyono. 2010. Metode penelitian Kuantitatif Kualitatif dan R\&D, Bandung: Penerbit Alfabeta.

[19] Sugiyono. 2012. Memahami Penelitian Kualitatif. Bandung: penerbit Alfabeta.

[20] Tjiptono, Fandy. 2002. Strategi Pemasaran. Yogyakarta: Penerbit Andi.

[21] Tjiptono, Fandy. 2012. Strategi Pemasaran. Yogyakarta: penerbit Andi. 